\title{
LAMP WITH THE REPRESENTATION OF THE GRIFFIN: THE CHRISTIANISATION OF PAGAN MOTIFS DURING LATE ANTIQUITY
}

\begin{abstract}
The paper deals with the so called griffin lamps. In the group of early Christian bronze lamps, a relatively large number of those with handles in the form of griffin-shaped protome have been preserved. Griffin lamps could be called the prototype of Late Antique production, owing to the manner in which stylistic and iconographic elements of the previous period were combined with the spirit of the age dominated by Christian religion and new Christian aesthetics. The lamps were made in various workshops of the Eastern Mediterranean in the second half of the fourth and fifth centuries. Judging from the total number of preserved copies and variations of the basic type, they enjoyed considerable popularity. Lamp decoration testifies that the Christians during the Late Antiquity period were very receptive to the linking of pagan and Christian motifs, since they did not so easily give up their old patrons and ritual practices.
\end{abstract}

KEYWORDS: early Christian lamps, griffin, gryphon, Apollo, cross.

Late antiquity is a period that J. Elsner calls the archetypal period of transition in art (Elsner, 2011, p. 26). The age, long seen as a decisive point signifying the decline and the end of the classical culture, caused by the crisis of the Late Roman Empire, is nowadays somewhat regarded as the first Renaissance of the classical world and the 
age in which the continuity of ancient culture can be traced, despite the great historical, ethnic, and religious changes. ${ }^{2}$ Thus, instead of hiatus in the history of civilisation - usually referred to as the Dark Ages - contours of the period marked by rich craft and artistic production were outlined, resulting in changes that represent the evolution of tendencies present in Roman art of the previous period, but likewise announcing the medieval aesthetics. On the one hand, the visual culture of Late Antiquity expresses traditionality and eclecticism, while on the other, there is innovation reflected in the synthesis of old forms, materials, and ornaments with a new function and meaning of objects, and a growing acceptance of oriental influences and 'barbaric' art. The cultural heritage of ancient Greece and Rome did not disappear during Late Antiquity, however, precisely this period enabled the continuity of classical forms in the medieval Mediterranean culture, and also mediated the spread of classical influences beyond the boundaries of the Mediterranean world. ${ }^{3}$

Applied art was flourishing in a turbulent world of Late Antiquity earmarked by strong social changes, religious transformation of the pagan world and the triumph of monotheism in the Mediterranean. Mass production of standardised art, as formulated by P. Brown, had its consumers in all layers of society and attested in particular to the religious and cultural atmosphere of the period (Brown, 1971, p. 40). Whether we are talking about objects of exceptional artistic quality or simple objects intended for 'mere mortals', the significance of messages they conveyed is equally noteworthy. The term minor arts which has been in use since the time of Vasari, as well as the determinants decorative or ornamental art, reflected an inferior position of applied arts in relation to architecture, sculp-

2 D. Hernández de la Fuente thinks it is justifiable to use this term for the period in which the interest for (classical) cultural tradition, understood as the source of our civilization, was renewed and reaffirmed, with Late Antiquity perceived as the fundamental basis for the transmission of classical heritage (Hernández de la Fuente, 2011, p. 1).

3 By means of cultural interaction, classical culture and art would influence the art of Persia under the Sasanids, as well as early Islamic art, especially the period of the Umayyads (Elsner, 2013, p. 26). P. Brown pointed out the unprecedented social and geographical expansion and opening in the period of Late Antiquity, including the democratisation of art and interculturalism (Brown, 2011, p. 23). The great social fluctuation saw the rise of a new elite, bringing new influences and likewise taking the role of the patron of luxury craft products, seeking to be rooted in the older tradition (Brown, 1971, pp. 31, 41). 
ture, and painting, persisting as such until the beginning of the $20^{\text {th }}$ century. Contemporary visual culture studies have significantly changed the attitude towards objects of applied art, recognising not only their artistic qualities, but also the meaning which has surpassed the utility function (Walker, 2012, pp. 169-172). One in a series of changes brought about by the period of Late Antiquity was manifested in the field of artistic production, purchase, and demand. In addition to, or better instead of, the need of possessing art objects of monumental dimensions, the taste for 'exceptional miniatures' was being developed (Elsner, 2006, p. 11). These are works of ivory, precious metals, glass, precious stones, illuminated manuscripts, but also numerous objects for everyday use, that often borrow iconographic patterns from subjects of high craft and artistic production. In the world of religious syncretism and mutual rivalry of various religions and cultures, the (religious) art of Late Antiquity was dedicated to the adherents of a particular religious group. By the message they conveyed, objects of artistic and craft production had an impact on the creation of collective identity, but at the same time, in the wider context of competitiveness between different cultures, they appear as a form of religious propaganda (Elsner, 2006, pp. 11-13). Vessels of light were particularly suitable for these requirements. They were easily portable, relatively affordable items, whose utility role of lighting spaces made them indispensable in facilities of different purposes. On the other side, there is a symbolic and religious significance attributed to these lamps in the Mediterranean culture, which was fully accepted by Christianity. Lamps had the role of cult objects, both in public and private piety, where the flame of the lamp signified the presence of an invisible God (Тешић Радовановић, 2018, pp. 166-167). The number of preserved lamps, their forms and the materials they were made of, as well as the fact that they were produced at different times, give them a documentary dimension since they reflect cultural and religious changes, but also an individual and intimate relationship towards religion (Schoolman, 2018, pp. 165-166).

In the group of early Christian bronze lamps, a relatively large number of those with handles in the form of griffin-shaped protome have been preserved. Griffin lamps could be called the prototype of the Late Antique production, owing to the manner in which stylistic and iconographic elements of the previous period were combined with the spirit of the age dominated by the Christian religion and new Christian aesthetics. Bronze lamps with griffin han- 
dles belong to the type 4 according to the classification given by M. Xanthopoulou. ${ }^{4}$ They were discovered throughout the Mediterranean, and one lamp of this type is kept at the National Museum in Belgrade. It was discovered incidentally, unearthed in the village of Panjevac near Despotovac. ${ }^{5}$ Judging from the total number of preserved copies and variations of the basic type, reflected in a slightly altered form of the griffin's body or head, or by added motifs such as dolphins, human figures, etc, the lamps were made in various workshops of the Eastern Mediterranean in the second half of the fourth and fifth centuries, enjoying considerable popularity. Among the most representative examples, the literature enlists a lamp from Herculanum - today kept at the British Museum, a lamp of unknown provenance at the Virginia Museum of Fine Arts in Richmond, Virginia, and a lamp with two nozzles, purchased in Istanbul, now housed at the DOC collection in Washington, DC (Xanthopoulou, 2010, pp. 161-172). A rather stylised and simplified version of the griffin lamp is to be found in the Rabbula Gospels. The lamp at the candelabrum is placed next to the representation of the evangelist (Bibl. Laur. cod. Plut. I, 56, f. 9 quoted in Xanthopoulou, 2010, pp. 15-16). In the Stuttgart Psalter we encounter a representation of a similar lamp, which may have been modelled after an older pattern (Stutt. Bilderps. I, f. 139r quoted in Xanthopoulou, 2010, p. 16). It seems that the miniaturist did not understand the decorative pattern, nor did they grasp the way the lamp functioned. The griffin has been transformed into a (good-natured) bird, and an excessive flame emerges from the nozzle of the lamp. However, the basic form of the lamp, and details such as the lid, pouring hole, and candelabrum it is set up on, have preserved Late Antiquity form.

4 Xanthopoulou identifies another type consisted of regional variants, containing a horse-shaped protome. Xanthopoulou has published 22 lamps with the protome in the shape of gryphon's head (Xanthopoulou, 2010, p. 14).

5 Inv. № 130/IV (Ilić, 2006, p. 53, pl. XIII/5; Jeličić, 1958-59, p. 79; Кондић, 1993, p. 337; Tatić-Đurić, 1960, pp. 237-248; Цвјетићанин, 2013, p. 215). 


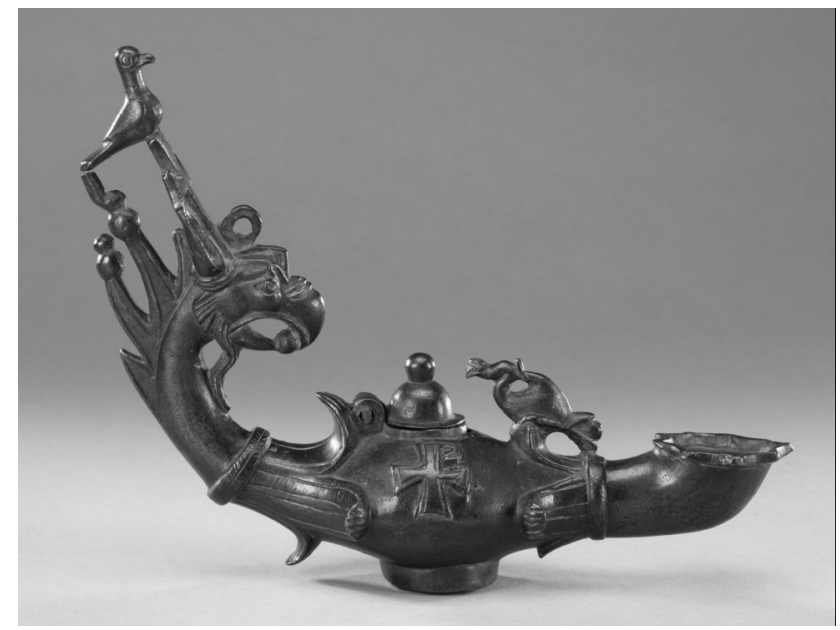

Fig. 1 LAMP With HANDle IN THE SHAPE OF A GRIFFIn's HeAD, VMFA. PhOto CREDITS: ARTHUR AND MARGARET GLASGOW Fund, Virginia MuSEUM OF FinE ARTS IN RICHMOND, VIRGINIA; СЛ. 1 ЛАMПА СА ДРШКОМ У ОБЛИКУ ГЛАВЕ ГРИФОHA, VMFA. PHoto: ARTHUR AND MARGARET GLASGOW Fund, Virginia MuSEUM OF FINE ARTS IN RICHMOND, VIRGINIA

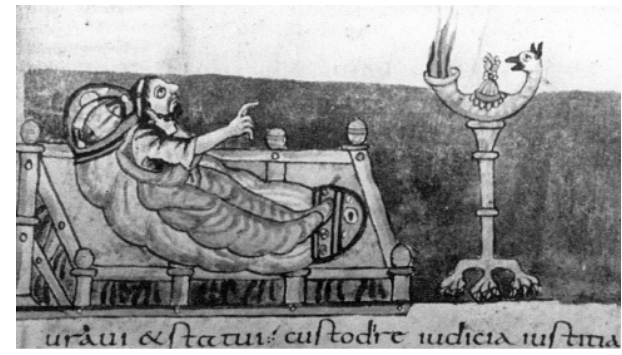

Fig. 2 Depiction of Griffin lamp from StUtTGart Psalter. STUtT. Bilderps. I, F. 139R QUOTED IN XANTHOPOULOU, 2010, Р. 16; СЛ. 2 ЛАМПА СА ГРИФОНОМ ИЗ ШТУТГАРСКОГ ПСАЛТИРА. STUTT. BILDERPS. I, F. 139R ПРЕMA XANTHOPOULOU, 2010, P. 16.

The lamp from the National Museum has the dimensions $21 \times 6.5$ $\times 16 \mathrm{~cm}$, which, judging from the analogies, was a standard size. It is characterised by a round body, depicted with the fleur-de-lys motif on both ends. In the middle of the body, on both sides, there is the Christ's monogram, or staurogram. The pouring hole is also placed in the middle of the body and once had a lid, which is now lost. On 
all lamps containing a lid, it is of dome-like shape with a bead at the top (Xanthopoulou, 2010, pp. 163-167). Going towards the lamp's handle and nozzle, there is a plastic ring embellished with transverse incisions. An elongated nozzle finishes in the form of a flower composed of nine petals, in whose centre is the opening for the wick. The handle is modelled in the shape of griffin's head. The mane is shown in the form of three triangular neck protrusions finishing in balls. The griffin's head is neatly modelled, with a bent beak containing a ball, while the ears are pointed. At the top of the head there is a staurogram, surmounted with the depiction of a dove. The lamp's foot is small and in the shape of a ring, whereas a petite ring intended for fastening the lamp is preserved on the griffin's head and body.

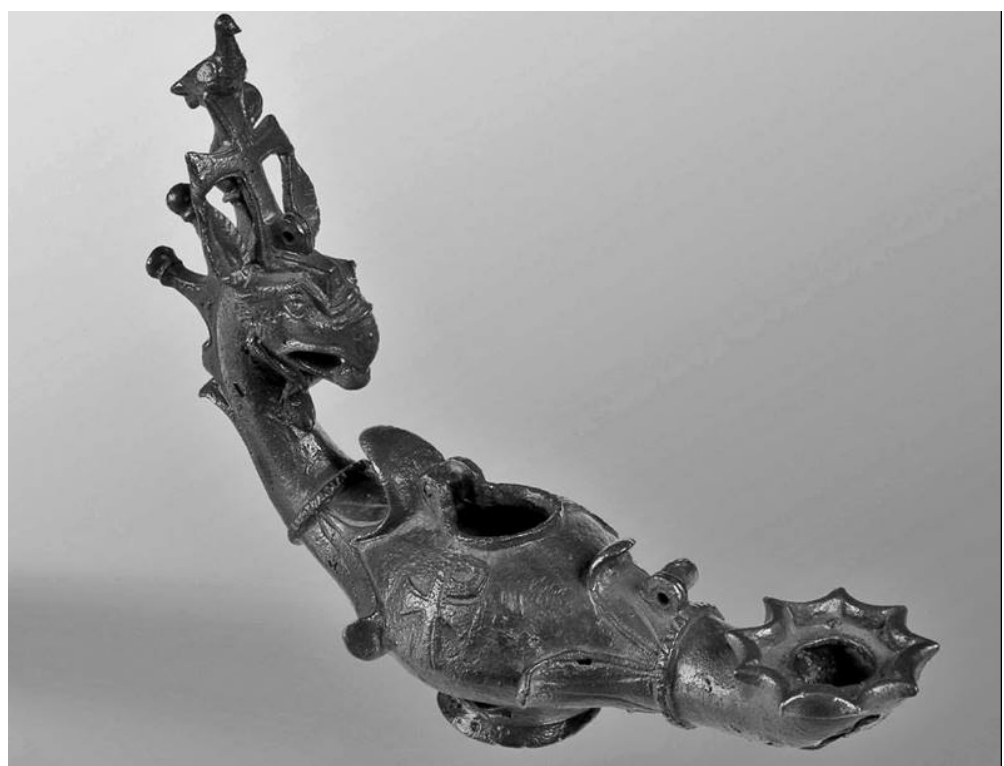

FIG. 3 LAMP WITH HANDLE IN THE SHAPE OF A GRIFFIN'S HEAD, NATIONAL MUSEUM BELGRADE. РНOTO IN PUBLIC USE; СЛ. 3 ЛАMПА СА ДРШКОМ У ОБЛИКУ ГЛАВЕ ГРИФОНА, НАРОДНИ МУЗЕЈ, БЕОГРАД. ФОТОГРАФИЈА У ЈАВНОЈ УПОТРЕБИ. 


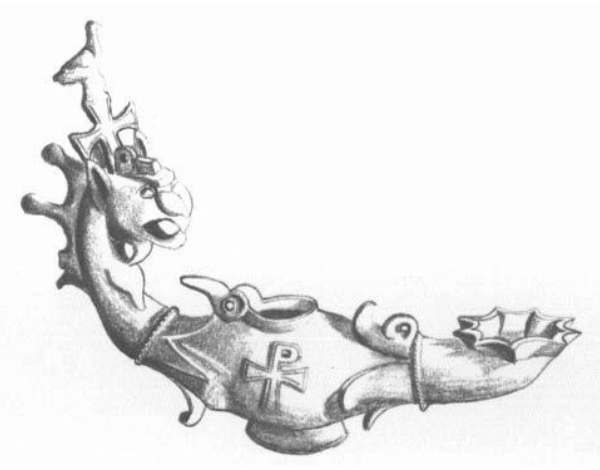

FIG. 4 DRAWING OF A LAMP WITH HANDLE IN THE SHAPE OF A GRIFFIN'S HEAD, NATIONAL MUSEUM BELGRADE, FROM Ilić, 2006, PL. XIII/5; СЛ. 4 ЦРTЕЖ ЛАMПЕ СА ДРШКОМ У ОБЛИКУ ГЛАВЕ ГРИФОНА, НАРОДНИ МУЗЕЈ, БЕОГРАД, ПРЕМА ILІС́, 2006, T. XIII/5.

The decorative repertoire of the lamp combines pagan and Christian symbols in the spirit of syncretism of Late Antiquity. Particularly interesting is the way in which this pagan motif was incorporated into Christian iconography and completely christianised. The griffin is a very old motif, related to the dignity of a ruler. The alchemical powers were attributed to it, and it often appears as a carrier of gods. In Mesopotamia, representations of griffins emerged already in the $3^{\text {rd }}$ millennium $B C$. They were also depicted at the Knossos Throne Room. In addition, in the Minoan and Mycenaean art, and later during the Greek archaic period, metal and ceramic vessels were often decorated with griffin-shaped protomes (Goldman, 1960, pp. 319-320; Reed, 1976, p. 365). It was the time when the griffin acquired the symbolism of a winged solar deity, based on the syncretism of the Egyptian-Mesopotamian solar cults. The Semitic root of the term griffin, seraph, denotes 'a fiery being' (Goldman, 1960, p. 328). In Greek mythology, griffins were mythical quadruped animals with the body of a lion, the head of an eagle, and flame-throwing eyes. They were primarily the symbol of Apollo, but sometimes associated with Artemis and Dionysus. Griffins were believed to live in India, Ethiopia or near the land of the Hyperboreans, where they guarded the gold. Since griffins combine the strength of a lion and the power of an eagle, they stood for symbols of divine powers and constant vigilance. They were also considered guardians of tombs, 
often appearing in funeral art (Goldman, 1960, pp. 320, 327; Srejović, Cermanović-Kuzmanović, 1992, p. 99).

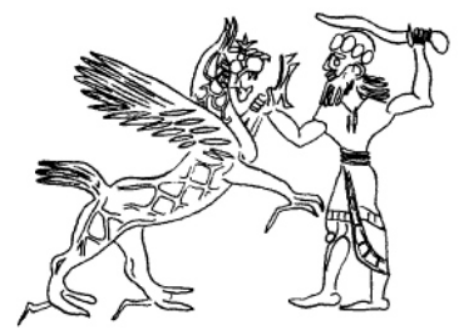

Fig. 5 DRAWING OF THE Lion-GRIFFIN, MiddLe ASSYRIAN FROM GoldMAN, 1960, PL. 89/8; СЛ. 5 ГРИФОН - ЛАВ, СРЕДњОАСИРСКИ ПЕРИОД, ПРЕМА GOLDMAN, 1960, PL. $89 / 8$.

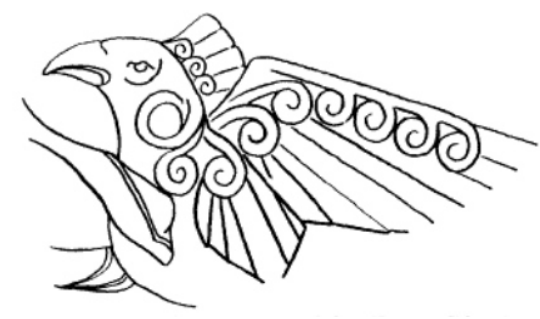

Fig. 5A DRAWING OF THE EAGLE-GRIFFIn, MYCENAEAN FROM GOLDMAN, 1960, PL. 89/5; СЛ. 5 ГРИФОН - ОРАО, МИКЕНСКИ ПЕРИОД, ПРЕМА GOLDMAN, 1960, PL. $89 / 5$.

In early Christian lamps, the griffin appears as a mythical being of great strength, closely related to the light and solar principles, being a sign of divine protection. By means of connecting pagan and Christian symbolism in the syncretism of Late Antiquity, the apotropaic and spiritual power of the griffin representation were being intensified. Nevertheless, the griffin with its flame-throwing eyes, reflecting Apollo's sacred principle, was still strongly connected with the pagan solar deity whom it symbolised. Apollo, the god of light, but also of intellectual enlightenment, who, assisted by the Muses, inspires poets, artists and thinkers, was perceived as a threat to Christ's authority (Jovanović, 2006, p. 13; Srejović, Cermanović-Kuzmanović, 1992, pp. 275-276). ${ }^{6}$ By placing the griffin, the symbol of pagan solar deity, on the lamp, it was directly 
brought into opposition with the light of Christ, symbolised by the lamp and accentuated twice by the monogram of Christ on the body of the lamp, whereas the third monogram is on the griffin's head. Already in the fourth century, the cross in the form of a monogram, that is, staurogram, acquired a recognisable Christian connotation and served as a sign enabling the ancient solar symbol of griffin to be invested with meanings of the new faith.

The cross is one of the universal symbols in the history of civilisation. It began to occur even in prehistory, when it was understood as a solar or astral symbol. As a variation of the motif of the cross and as a symbol of the sun, the swastika, or crux dissimulata, often emerged after the Neolithic revolution, when, due to the transition to agriculture, people increasingly associated their annual cycles with the cyclical movement of the sun. ${ }^{7}$ Prior to the appearance of the cross as a Christian symbol, the one in the shape of an ankh (lat. crux ansata) dominated the Egyptian art, symbolising eternal life (Dimitrova, 1995, p. 13). As a graphic sign, the cross suited the nature of early Christian art, having the reduction of the meaning to the image-sign as one among important traits, as elaborated by A. Grabar. In this sense, the essence of religion could be presented through simple representations, that, instead of describing, suggested a deeper meaning, leaving to the observer's intuition to ponder upon the symbolic layers of the representation. In order for this system to be functional, signs that are clear and unambiguously understandable would be required and, in that regard, the cross gained primacy in comparison to other symbols that had been more dominant at the time of the emergence of Christian visual culture (Baert 2004, p. 20; Grabar, 1968, p. 8; Jensen 2000 , p. 36). Symbols such as fish, a ship, the Good Shepherd or dove were highly popular in the pagan culture of Antiquity and could have easily attained non-Christian associations (Chrzanovski, Zhuravlev, 1998, pp. 114-118).

The theology of the cross was formed by the end of the first and throughout the second centuries. Numerous references to the cross, especially their appearance in the Old Testament, and salvation through the Saviour who gave His life upon the Cross were

\footnotetext{
http://museum.doaks.org/OBJ27320.htm, accessed June 18, 2018.

7 The four, or three swastikas presented on the Vršac Carriage or the Dipylon vases are symbolically associated with the solar deity Apollo who was said to winter in the land of the Hyperboreans and spend the rest of the year in the south (Jovanović, 2007, pp. 9-11).
} 
found in the First Apology of Justin Martyr (Iust. Mart. Apol. Maior, LV). Tertullian explains the custom of raising hands during the prayer, or the gesture of orant, as the imitation of the posture of Christ on the Cross, while Marcus Minucius Felix makes the same comparison with the purpose of pointing out that the motif of the cross is to be found in everyday sights, such as the mast or the anchor of a ship (Jensen, 2000, p. 36). According to the written theological literature, the cross was at first incorporated into other motifs of Christian visual culture, most often the anchor. Also, as part of epitaphs of the mid-2 ${ }^{\text {nd }}$ century, the pronounced letter X or $\mathrm{T}$ is interpreted as a Christian sign, or the cross. From the third century onwards, the cross became common in visual representations and in various variants: in the form of the letter T (crux commissa), the Greek cross (crux quadrata), the Latin cross (crux capitata), and finally the pre-Constantinian monogram emerging towards the end of the century (Dimitrova, 1995, pp. 13-19).

The cross has a complex meaning, but it is primarily a substitute of Christ and the symbol of His glory and Crucifixion. The triumphal aspect of the symbolism of the cross and its recognisable meaning has definitely been formed after 313 , in the period marked by the expansion of various representations and types, as well as the appearance of the Christogram and staurogram (Dimitrova, 1995, p. 20-29). The perception of the cross as a prominent Christian symbol is directly related to Constantine's vision preceding the Battle of the Milvian Bridge. For Constantine, a cross of light appearing in the sky became a well-known apotropaic sign which he included in the imperial insignia. Eusebius describes the imperial vexillum as being covered with gold and precious stones, and probably did have the form of Christ's monogram framed by laurel wreath (Baert 2004, pp. 16-17; Euseb. Vita Const. I, XXXI). Thus, apart from the soteriological and eschatological dimensions, the cross became associated with the imperial ideology, as a verified tropaion. B. Baert highlights another aspect of Constantine's vision - a cross of light triumphing over the sun. She considers that the description of the emperor's vision was expanded by Eusebius with the idea of the triumph of the cross, signifying the triumph of Christianity over pagan cults, or the victory of Christ the True Sun over the Unconquered Sun, Sol Invictus, honoured by Constantine to that point. As an imperial insignia and symbol of the triumphant Church, the cross became a more frequent motif during the fourth 
century, being depicted in monumental art, but likewise on personal and utility items (Baert 2004, pp. 17-21).

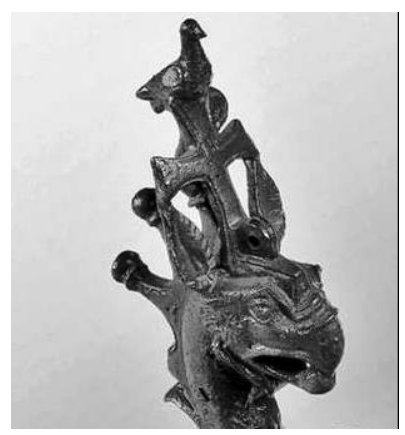

Fig. 6 DetAIL OF THE LAMP WITH HANDLE IN THE SHAPE OF A GRIFFIN'S HEAD, NATIONAL MUSEUM BELGRADE. РНOTO IN PUBLIC USE; СЛ. 3 ЛАMПA CA ДРШКОМ У ОБЛИКУ ГЛАВЕ ГРИФОНА, ДЕТАЉ, НАРОДНИ МУЗЕЈ, БЕОГРАД. ФОТОГРАФИЈА У ЈАВНОЈ УПОТРЕБИ.

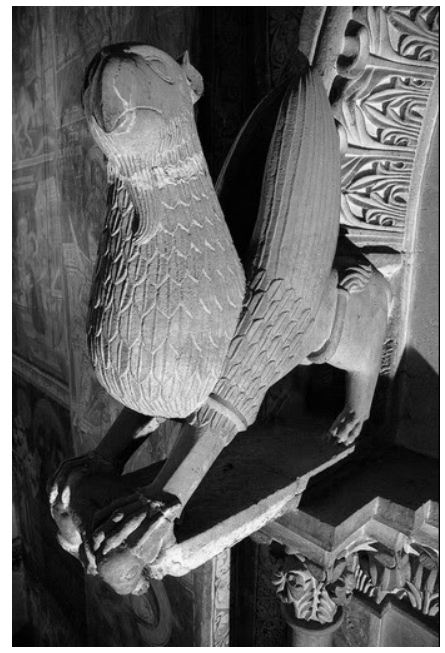

Fig. 7 Griffin from the NAVe Portal of THe CHURCh of Christ Pantocrator, DeČANI MONASTERY, XIV CENTURY. РНOTO IN PUBLIC USE; СЛ. 7 ГРИФОН СA УНУТРАШЊЕГ ПОРТАЛА ЦРКВЕ ХРИСТА ПАНТОКРАТОРА, МАНАСТИР ДЕЧАНИ, ХІV ВЕК. ФОТОГРАФИЈА У ЈАВНОЈ УПОТРЕБИ.

The association between the motifs of the cross and the griffin, or more precisely, the triumph of the first over the latter symbol has a basis in early Christian writings. The contest between Christ 
and Apollo is also a topic dealt with by early Christian authors. Thus, in his Poem X Paulinus of Nola speaks of Christ as the only True Sun, whose brightness leads to salvation, while only the ignorant address the deaf deity at Delphi and attribute divine qualities to the muses (Paulini, Poem X, 25, 50). Through the representation of the griffin from whose head rises the staurogram with the dove of the Holy Spirit, Christ the True Sun and veritatis lumen triumphs over Apollo. The dove of the Holy Spirit confirms that the light which Christ brings is not only the sun's light necessary for the sense of sight, but the light of true enlightenment as well.

The popularity of the lamp, confirmed by a large number of preserved copies, testifies that the people of the period of Late Antiquity were very receptive to the linking of pagan and Christian motifs, since they did not so easily give up their old patrons and ritual practices. Therefore, a new challenge arose before the Christian theology: how to reconcile the Christian understanding of the world with the habits of the man of Antiquity. Compromises, such as this one, were not an isolated phenomenon in this process. Pagan motifs were suitable for borrowing, but were also regarded as necessary in the formation of Christian visual culture. By means of recontextualisation and resemantisation, they were not reduced to ornaments, but took on a completely new meanings, most often in the spirit of interpretatio christiana. ${ }^{8}$ When it comes to griffin lamps, in order to neutralise an unacceptable connection with the pagan deity of light, but also of healing and enlightenment, ${ }^{9}$ the apotropaic symbol of griffin was christianised and subordinated to Christ's true light and enlightenment, with the assistance of the cross as the Christian apotropaic sign, being the symbol of both Christ's and Constantine's triumph. ${ }^{10}$ Over the course of time, the link between the griffin and Apollo was suppressed, while the apotropaic meaning of the symbol - the one of the guardian of tombs and sacral spaces - came to the fore, surviving into the Middle Ages and later. Through the representation of the griffin dragging the

8 Illustrative examples are antique gemmas and cameos, with portraits of emperors or empresses, that became the part of Christian reliquaries, bindings of the Gospels and other liturgical objects, such as the Herimann's Cross, probably made for one of the members of the Ottonian dynasty (Kinney, 2006, pp. 235236).

9 The Christians resisted the pagan gods possessing healing powers, such as Apollo or Asclepius. These powers evened them with Christ, thus questioning His uniqueness. 
chariot of Alexander the Great, this motif would be tied with the image of a great and powerful ruler, enjoying the protection of gods (Evans, Holcomb, Hallman, 2001, pp. 58-59). The depiction on the lamp can therefore be interpreted as one of the phases in the appropriation of the pagan motif into the Christian sphere and a step in the process of resemantisation and ultimate Christianisation.

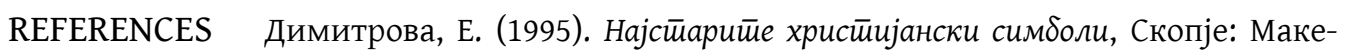
донска цивилизација.

Јеличић, Б. (1958/9). Бронзани жишци у Народном музеју, ЗРНМ II, 72-86.

Кондић, J. (1993). Лампа кат. 145, in: Д. Срејовић, (Ed.), Римски изарски

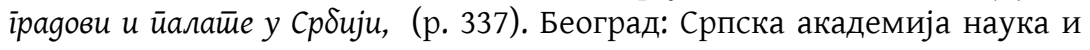
уметности.

Срејовић, Д., Цермановић-Кузмановић, А. (1992). Речник ірчке и римске мийолоїија. Београд: Српска књижевна задруга.

Татић-Ђурић, М. (1960). Једна касноантичка лампа из збирке Народног Музеја у Београду, Жива Анӣика X, 237-247.

Тешић Радовановић, Д. (2018). Светиљка као симбол у теологији и иконологији светлости на простору Медитерана, 3ठорник раgова

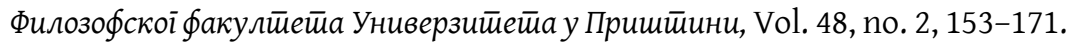

Цвјетићанин, Т. (2013). Приватна побожност. Предмети хришћанског култа у свакодневном животу, in: И. Поповић, Б. Борић Брешковић,

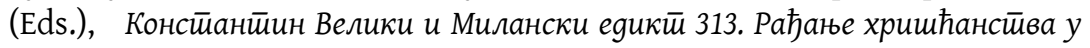

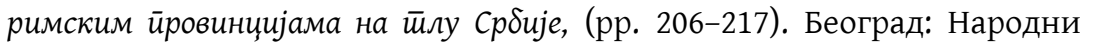
музеј.

Baert, B. (2004) A Heritage of Holy Wood: The Legend of the True Cross in Text and Image, Leiden-Boston: Brill.

Brown, P.R.L. (1971). The world of late antiquity, AD 150-750: from Marcus Aurelius to Muhammad, London: Thames and Hudson.

Brown, P.R.L. (2011). Late antiquity: Anomaly and Order Between a Pagan and a Christian World In: A. Lazaridou, (Ed.), Transition to Christianity: Art of

10 The placing of the cross on gryphon's head also draws an analogy to the incision of the cross on pagan sculptures, tombstones, or temples. Through the practice known as sphragis, pagan objects or items of pagan provenance were purified and 'baptized' via the incision of the cross, which, according to belief, neutralised their pagan aspect, so that they could be used in a new context (Kiilerich, 2006, p. 102; Chalkia, Lazaridou, 2011, p. 18). 
Late Antiquity, 3rd - 7th Century AD, (pp. 21-25). New York: Alexander S. Onassis Public Benefit Foundation.

Chalkia, E., Lazaridou, A. (2011). Preface. In: A. Lazaridou (Ed.), Transition to Christianity : art of Late Antiquity, 3rd-7th century AD, (pp. 15-20). New York: Alexander S. Onassis Public Benefit Foundation .

Chrzanovski, L., Zhuravlev, D. (1998). Lamps from Chersonesos in the State Historical Museum, Moscow, Roma: "L'Erma" di Bretschneider.

Elsner, J. (2006). Late Antique Art: The Problem of the Concept and the Cumulative Aesthetic, In: S. Swain, M. Edwards, (Eds.), Aproaching Late Antiquity: The Transformation from Early to Late Empire (pp. 1-41). Oxford: Oxford University Press. DOI 10.1093/acprof:oso/9780199297375.001.0001

Elsner, J. (2011). Late Antiquity: a Period of Cultural Interaction, In: A. Lazaridou, (Ed.), Transition to Christianity: Art of Late Antiquity, 3rd - 7th Century AD, (pp. 26-31). New York: Alexander S. Onassis Public Benefit Foundation.

Eusebius Caesariensis, Vita Constantini, In: Eusebius of Caesarea The Life of the Blessed Emperor Constantine, from: Nicene and Post-Nicene Fathers Vol. I, (eds.) P. Schaff, H. Wace, Grand Rapids 1955.

Evans, H.C., Holcomb, R., Hallman M. (2001). "The Arts of Byzantium", The Metropolitan Museum of Art Bulletin, v. 58, no. 4 .

Goldman, B. (1960). The Development of the Lion-Griffin, AJA Vol. 64, № 4, 319-328.

Grabar, A. (1968). Christian Iconography: A Study of Its Origins, Princeton: Princeton University Press.

Hernández de la Fuente, D. (2011). Preface: New Perspectives on Late Antiquity, In: D. Hernández de la Fuente, (Ed.), New Perspectives on Late Antiquity, (pp. 1-5). Newcastle upon Tyne: Cambridge Scholars Publishing.

Ilić, O. (2006). Ranohrišćanski import na teritoriji severnog Ilirika u periodu od IV do početka VII veka, Arheologija i prirodne nauke 2, 47-68.

Iustini philosophi et martyris Apologiae pro Christianis, in: Patristische Texte und Studien 38, (trans.) M. Markovich, Berlin-New York 1994.

Jensen, R. (2000). Understanding Early Christian Art, London: Routledge.

Jensen, R. (2017). The Cross: History, Art, and Controversy, Cambridge, MA: Harvard University Press.

Kinney, D. (2006). The Concept of Spolia, In: C. Rudolph (Ed.), A Companion to Medieval Art: Romanesque and Gothic in Northern Europe (pp. 233-252). Oxford: Blackwell Publishing Ltd. doi: 10.1002/9780470996997.ch11

Paulini, Poemata, X Ausonio Paulinus in: The Poems of St. Paulinus of Nola, Ancient Christian Writers, vol. 40, (transl) P. G. Walsh, New York-Paramus 1975, 58-59. 
Reed, N. B. (1976). Griffins in Post-Minoan Cretan Art, Hesperia 45, 364-379.

Schoolman, E.M. (2018). Image and Function in 'Christian' and 'Pagan' Late Antique Terracotta Lamps, In: M. Saghy, E. M. Schoolman, (Eds.), Pagans and Christians in the Late Roman Empire: New Evidence, New Approaches (4th-8th centuries) (pp. 165-177). Budapest: CEU Press.

Walker, A. (2012). „The Art That Does Not Think“: Byzantine „Decorative Arts“ - History and Limits of a Concept, In: C. Hourihane, (Eds.), From Minor to Major. The Minor Arts in Medieval Art History, (pp. 169-193). Princeton: The Index of Christian Art, Princeton University.

Xanthopoulou, M. (2010). Les lampes en bronze à l'époque paléochrétiene, Turnhout: Brepols Publishers.

\author{
ДАНИЈЕЛА Т. ТЕШИЋ РАДОВАНОВИЋ \\ УНИВЕРЗИТЕТ У ПРИШТИНИ С ПРИВРЕМЕНИМ СЕДИШТЕМ \\ У КОСОВСКОЈ МИТРОВИЦИ, ФИЛОЗОФСКИ ФАКУЛТЕТ \\ КАТЕДРА ЗА ИСТОРИЈУ УМЕТНОСТИ
}

РЕЗИМЕ

СВЕТИЉКА СА ПРЕДСТАВОМ ГРИФОНА:

ХРИСТИЈАНИЗАЦИЈА ПАГАНСКИХ МОТИВА ТОКОМ КАСНЕ АНТИКЕ

Период касне антике, обележен снажним друштвеним променама, религиозном трансформацијом паганског света и тријумфом монотеизма на простору Медитерана, представља архетипски период транзиције у уметности. Визуелна култура раздобља на једној страни испољава традиционалност и еклектицизам, док на другој стоји иновативност која се огледа у синтези старих форми, материјала и орнамената са новом функцијом и значењем предмета, повезаним пре свега са потребама хришћанске уметности, али и све израженијим прихватањем оријенталних утицаја и „варварске“ уметности. Религиозни и културни синкретизам периода утицао је на трансформацију великог броја старијих, паганских мотива и њихово прилагођавање захтевима хришћанске култне праксе. Тенденције су се јасно испољиле на предметима примењене уметности, међу којима су посебно илустративне уљане светиљке, због начина на који комбинују утилитарну и симболичку функцију у религиозном контексту.

У групи ранохришћанских бронзаних светиљки сачуван је релативно велики број лампи са ручком у облику протоме грифона. Светиљке са грифоном могле би се назвати прототипом касноантичке уметничке продукције, због начина на који спајају 
стилске и иконографске елементе претходног раздобља са духом времена у коме доминирају хришћанска религија и нова хришћанска естетика. Једна светиљка овог типа, која представља случајан налаз из села Пањевац у близини Деспотовца, чува се у Народном музеју у Београду. Оठликом, величином и квалитетом израде лампа се приближава другим примерцима произведеним у радионичким центрима Источног Медитерана, који су откривени широм Европе и Медитерана. Декоративни репертоар лампе спаја мотив грифона, пагански соларни симбол блиско повезан са Аполоном, са хришћанским мотивима крста и голуба. У раду се истражују начини на који су ови мотиви доведени у везу и процес којим је пагански мотив грифона трансформисан у апотропејски симбол прихватљив за хришћане.

КљУчнЕ РЕчи: ранохришћанске светиљке; грифон; Аполон; крст.

Овај чланак је објављен и дистрибуира се под лиценцом Creative Commons Ауторство-Некомерцијално Међународна 4.0 (CC BY-NC 4.0 |

https://creativecommons.org/licenses/by-nc/4.0/).

This paper is published and distributed under the terms and conditions of the Creative Commons Attribution-NonCommercial International 4.0 licence (CC BY-NC 4.0 | https://creativecommons.org/licenses/by-nc/4.0/). 